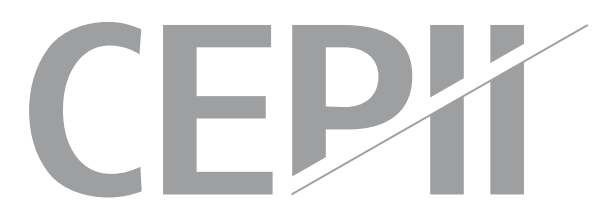

\title{
Oil currencies in the face of oil shocks: What can be learned from time-varying specifications?
}

Jean-Pierre Allegret, Cécile Couharde

Valérie Mignon \& Tovonony Razafindrabe

\section{Highlights}

- Real exchange rates react significantly to oil demand and oil market specific shocks, in contrast to supply disturbances.

- Response to oil market specific shocks has been mostly effective in important oil-producing countries, while being inexistent in smaller oil producers.

- Significant evolutions and differences across countries and over time suggest that there is no single model of oil currencies. 


\section{Abstract}

While the oil currency property is clearly established from a theoretical viewpoint, its existence is less clear-cut in the empirical literature. We investigate the reasons for this apparent puzzle by studying the time-varying nature of the relationship between real effective exchange rates of five oil exporters and the real oil price in the aftermath of the oil price shocks of the last two decades. Accordingly, we rely on a time-varying parameter VAR specification which allows the responses of real exchange rates to different oil price shocks to evolve over time. We find that the reason of the mixed results obtained in the empirical literature is that oil currencies follow different hybrid models in the sense that oil countries' real exchange rates may be driven by one or several sources of oil price shocks that furthermore can vary over time. In addition to structural changes affecting oil countries, structural changes arising from the oil market itself through the various, time-varying sources of oil price shocks are found to be crucial.

\section{Keywords}

Oil currencies, Oil shocks, Time-Varying Parameter VAR model.

I JEL

C32, F31, Q43.

\section{Working Paper}

\section{CEPI}

CEPII (Centre d'Etudes Prospectives et d'Informations Internationales) is a French institute dedicated to producing independent, policyoriented economic research helpful to understand the international economic environment and challenges in the areas of trade policy, competitiveness, macroeconomics, international finance and growth.
CEPII Working Paper

Contributing to research in international economics

(c) CEPII, PARIS, 2015

All rights reserved. Opinions expressed in this publication are those of the author(s) alone.

$\begin{array}{ll}\text { Editorial Director: } & \text { CEPII } \\ \text { Sébastien Jean } & \begin{array}{l}\text { 113, rue de Grenelle } \\ 75007 \text { Paris } \\ \text { Production: }\end{array} \\ \text { Laure Boivin } & +33153685500 \\ & \text { www.cepii.fr } \\ \text { No ISSN: } 1293-2574 & \text { Press contact: presse }\end{array}$




\title{
Oil currencies in the face of oil shocks: What can be learned from time-varying specifications?•
}

\author{
Jean-Pierre Allegret* \\ Cécile Couharde* \\ Valérie Mignon** \\ Tovonony Razafindrabe ${ }^{*}$
}

\section{Introduction}

It is a widely accepted view that many commodity-exporting countries have commodity currencies, in that movements in real commodity prices can explain fluctuations in their real exchange rates (Chen and Rogoff, 2003; Cashin et al., 2004). Among those commodities, oil has been identified as a potential driver of currencies as movements in the real price of oil can also have significant influence on oil producers' real exchange rates (Korhonen and Juurikkala, 2009; Coudert et al., 2011).

On a theoretical level, two main arguments have been put forward to explain the existence of oil currencies. First, higher oil prices may bring about an appreciation of real exchange rates through mechanisms that have been identified by the literature on the Dutch disease (Corden, 1984) and on commodity currencies (Chen and Rogoff, 2003). Higher oil prices lead to an improvement in terms of trade which in turn increases revenues from the oil exports. This effect, by raising the price of non-traded goods, may place appreciation pressures on the real exchange rate. Second, exchange rates of oil countries can also experience a 'wealth effect' through the specific impact of oil price changes on international portfolio decisions and trade balances (Krugman, 1983; Golub, 1983). According to this view, oil-exporting countries can encounter a wealth transfer driven by the improvement of their net foreign asset position if the oil price rises.

The empirical literature has, however, provided mixed support for the assumed relationship between the oil price and real exchange rates of oil-producing countries. Studies relying on panel data mostly find that real exchange rates of oil producers appreciate in the wake of increased oil prices, confirming the relevance of oil currencies (Korhonen and Juurikkala, 2009; Coudert et al., 2011). Country-by-country studies lead, however, to less clear-cut

\footnotetext{
- This research has been supported by the French Energy Council (Conseil Français de l'Energie), Paris, France. Corresponding author: Valérie Mignon, EconomiX-CNRS, University of Paris Ouest, 200 avenue de la République, 92001 Nanterre Cedex, France. Email: valerie.mignon@u-paris10.fr.

${ }^{*}$ EconomiX-CNRS, University of Paris Ouest, France.

${ }^{* *}$ EconomiX-CNRS, University of Paris Ouest and CEPII, France.
} 
findings with some cross-country differences. For example, Habib and Kalamova (2007) do not find a long-run relationship between real effective exchange rates and oil prices for Norway and Saudi Arabia, while they report evidence for Russia. Mohammadi and JahanParvar (2012) find significant long-run effects of oil prices on real exchange rates only in 3 economies (Bolivia, Mexico and Norway) over a sample of 13 oil-exporting countries. Figure 1 , which depicts the evolution of the real oil price and real effective exchange rates (REER) of five oil producers, illustrates those mixed empirical results. The oil price boom observed since 1999 has not been followed by an appreciating trend of the REER in all the five countries. The REER has only appreciated in Canada, Norway and Indonesia; it has even slightly depreciated in the United Kingdom, while remaining broadly constant in Saudi Arabia. This configuration also contrasts with the 1970s over which rises in the oil price, for the two latter countries, went hand in hand with an appreciating trend of their respective REER. Overall, trends do not indeed indicate any obvious relationship between the two variables.

\section{Insert Figure 1 about here}

Such empirical findings are puzzling with regard to the theoretical litterature and the widely shared belief that the oil price is an important driver of the major fluctuations observed in oil producers' real exchange rates. One interpretation is that the relationship between the oil price and real exchange rates is somewhat weak. Coudert et al. (2011), reviewing the empirical studies on commodity and oil currencies, report and find a real exchange rate longrun elasticity with respect to the terms of trade lower for oil-exporting countries than for commodity-exporting economies. The authors explain this lower sensibility by (i) greater fluctuations in the oil price than in other commodity prices, and (ii) the pegged exchange-rate regime adopted by many oil-exporting countries that dampens the adjustement of the real exchange rate to the oil price movements.

The other interpretation is that the common belief is not baseless, but the puzzle arises from the empirical approach used to estimate the relationship between oil prices and real exchange rates. Indeed, the literature investigating the macroeconomic effects of oil price shocks has recently highlighted the importance of identifying the sources of those shocks. In particular, there is some evidence that the sources of changes in oil prices vary over time. Several authors (see, e.g., Hamilton, 2003; Barsky and Kilian, 2004) have argued that in the most recent decades, many fluctuations have been primarily demand driven. As a consequence, a large body of research has shown that macroeconomic variables could respond differently to an oil price change depending on the nature of the underlying shock. Those findings also have important methodological implications. Indeed, estimates based on the economic effects of an average oil price shock determined by a combination of supply as well as demand factors, can seriously bias cross-country comparisons. 
Aware of this methodological problem, some studies have investigated the relationship between the price of oil and real effective exchange rates using Kilian's (2009) methodology to decompose oil market shocks (Buetzer et al., 2012; Atems et al., 2015). Overall, these studies converge towards an univocal stylized fact: the underlying source of the oil price increase is crucial to determine the repercussions of oil shocks on exchange rates. Interestingly, while this finding might simply reflect structural changes experienced by the oil market itself through the increase in the relative importance of expansionary global shocks (Kilian, 2009; Baumeister and Peersman, 2013a), this literature offers complementary explanations that the effect of oil price shocks may also depend on some structural changes likely to influence the joint dynamics of the two macroeconomic variables (Buetzer et al., 2012; Peersman and Van Robays, 2012).

Against this background, we examine oil shocks' transmission mechanisms to real exchange rates over time and the driving forces behind the observed time variation. Accordingly, we take into account the different sources of oil price shocks usually highlighted by the literature (Kilian, 2009) by distinguishing (i) exogenous disruptions in oil supply, (ii) oil demand shocks driven by global economic activity, and (iii) oil market specific demand shocks caused by speculative or precautionary motives. We explore the time-varying dimension of the relationship between real exchange rates and oil prices by relying on a time-varying parameter VAR (henceforth TVP-VAR) specification. Indeed, the main advantage of the TVP-VAR is to allow oil shock effects and the oil price transmission to real exchange rates to vary over time; a property which is essential to capture the time-changing effects of shocks.

Our contribution to the literature is twofold. First, we go beyond the previous studies on oil shocks effects which mainly (i) rely on structural VAR or panel specifications with fixed coefficients (Buetzer et al., 2012; Atems et al., 2015), or (ii) introduce a structural break in the relationship between the real price of oil and real exchange rates in the mid-1980s to further investigate changes in the relationship between these two variables (Peersman and Van Robays, 2012). Second, by identifying and estimating the effects of oil price shocks depending on their underlying source, our analysis provides an additional contribution to the literature on oil currencies which, despite outlining the existence of a non-linear relationship between real exchange rates and oil prices (Akram, 2004; Mohammadi and Jahan-Parvar, 2012; Ahmad and Moran Hernandez, 2013; Beckmann and Czudaj, 2013), has the major disadvantage of assuming exogenous oil price shocks.

Considering a sample of five oil exporters over the 1988Q1-2013Q2 period, our main findings give additional insights to the oil price - real exchange rate nexus. First, we observe significant time variation in the relationship between the oil price and real exchange rates, whose identification enables us to add new contributions to the commodity currency 
literature. Second, we show that there are significant differences in those responses depending on the source of the oil shock. In particular, we find that (i) real exchange rates react significantly to oil demand and oil market specific shocks, in contrast to supply disturbances, and (ii) the respective importance of oil demand and oil market specific shocks evolves through time in all countries and tends to offset each other. Finally, depending on both the type of shocks and the time period considered, our analysis reveals significant evolutions and differences for a given country and across countries, meaning that there is no single model of oil currencies.

The rest of the paper is organized as follows. Section 2 presents the time-varying structural VAR model adopted in the paper. Results and related comments are displayed in Section 3. Section 4 summarizes our main findings and draws some concluding remarks.

\section{Empirical methodology}

We go further than the previous literature by aiming at better capturing the time-varying nature of the oil price-real exchange rate nexus. Specifically, we account simultaneously for two key characteristics of this relationship: the existence of abrupt movements and the presence of gradual changes, due to the persistence induced by some potential dampening factors (foreign reserves, adaptive learning behavior of agents...). To this end, we rely on the TVP-VAR model with sign restrictions. ${ }^{1}$

Such methodology is highly appealing for our purpose for two main reasons. First, it permits to model both the possible abrupt breaks and gradual evolution of the relationship between the variables of interest, but also to capture non-linearities. Indeed, the relationship between oil prices and the relevant macroeconomic variables might either be subject to structural changes $^{2}$ that come from economic events (e.g., the 2008 global crisis), economic policy decisions (OPEC decisions), political and social events (e.g., war and civilian unrest), fluctuations in the oil intensity of economic activity, changes in the regulation of oil and other energy markets, or present persistence due to adaptive learning behavior of agents (Primiceri, 2005). In addition, the transmission mechanism of oil price movements into macroeconomic variables might follow a non-linear process (Akram, 2004; Mohammadi and

\footnotetext{
1 In the aftermath of the seminal paper by Kilian (2009) - arguing that changes in the real oil pricemacroeconomic variables relationship over time are due to the time-varying nature of oil price shocks-TVPVAR models with sign restrictions have been used, for instance, by Peersman and van Robays (2009), Hahn and Mestre (2011), and Baumeister and Peersman (2013a).

${ }^{2}$ Cashin et al. (2004) and Le and Chang (2013) in a time series context, and Chen and Chen (2007) in a panel framework provide a formal test. Chen et al. (2010) advanced the necessity of controlling for structural breaks and time-varying parameters to uncover (in-sample) causality from commodity prices to the exchange rate.
} 
Jahan-Parvar, 2012; Ahmad and Moran Hernandez, 2013) with effects that can be different depending notably on the economic environment. Therefore, letting the data to determine whether the relationship between the real exchange rate and the oil price either presents a structural break or is persistent, and capture possible non-linearities in the reaction of the exchange rate to oil price changes are valuable features of the TVP-VAR approach. Second, identifying structural shocks using the sign restriction methodology allows us to assess the responses of the real exchange rate following different sources of oil price fluctuations, namely oil supply, global oil demand and oil market specific shocks.

\subsection{The TVP-VAR model}

The structural VAR representation of a multivariate time series model with both time-varying coefficients and time-varying standard errors of structural innovations is defined as:

$$
B_{t} Y_{t}=d_{t}+C_{1, t} Y_{t-1}+\cdots+C_{p, t} Y_{t-p}+\Sigma_{t} v_{t}
$$

where $Y_{t}=\left[\Delta \ln \left(q_{t}\right), \Delta d c_{t}, \Delta \ln \left(p_{o, t}\right), \Delta \ln \left(\text { reer }_{t}\right)\right]^{\prime}$ is an $4 \times 1$ vector of endogenous variables, with $\Delta$ denoting the first-difference operator. $q_{t}, d c_{t}, p_{o, t}$ and reer $_{t}$ respectively denote the world oil production, the dry-cargo index of Kilian (2009) used as a proxy of the global economic activity, the real oil price, and the real effective exchange rate. ${ }^{3} d_{t}$ is a vector of time-varying constants, $C_{i, t}(i=1, \ldots, p)$ are $4 \times 4$ matrices of time-varying coefficients on the lags of the endogenous variables and $v_{t}$ is a vector of structural innovations which are assumed to follow a multivariate standard normal distribution. As in Baumeister and Peersman (2013a), the lag length is set to $p=4$ in order to fully capture delays in the transmission of oil shocks (see also Hamilton, 2008).

We assume that the matrix of time-varying contemporaneous coefficients $B_{t}$ is lower triangular with one along its diagonal elements, whereas the matrix of time-varying standard errors $\Sigma_{t}$ is diagonal:

$$
B_{t}=\left(\begin{array}{cccc}
1 & 0 & \ldots & 0 \\
b_{21, t} & 1 & \ddots & \vdots \\
b_{31, t} & b_{32, t} & 1 & 0 \\
b_{41, t} & b_{42, t} & b_{43, t} & 1
\end{array}\right) \text { and } \Sigma_{t}=\left(\begin{array}{cccc}
\sigma_{1, t} & 0 & \ldots & 0 \\
0 & \sigma_{2, t} & \ddots & \vdots \\
\vdots & \ddots & \sigma_{3, t} & 0 \\
0 & \ldots & 0 & \sigma_{4, t}
\end{array}\right)
$$

Time variation in the relationship between our considered variables might derive from changes in (i) the contemporaneous relationship, (ii) the propagation mechanism, and (iii) the size of the shock that hits the model. Thus, the time-varying property of the parameters of

\footnotetext{
${ }^{3}$ See Section 3.1 for details concerning data.
} 
interest $B_{t}, C_{i, t}(i=1, \ldots, p)$ and $\sigma_{j, t}(j=1, \ldots, 4)$ lets the data determining the nature of changes that affect the link between the considered variables.

The reduced-form representation of the structural model (1) is defined as follows:

$$
Y_{t}=c_{t}+A_{1, t} Y_{t-1}+\cdots+A_{p, t} Y_{t-p}+\varepsilon_{t}
$$

where $A_{i, t}=B_{t}^{-1} C_{i, t}(i=1, \ldots, p)$ are matrices of lagged coefficients, $c_{t}=B_{t}^{-1} d_{t}$ is the vector of time varying coefficients that multiply constant terms and $\varepsilon_{t}=B_{t}^{-1} \Sigma_{t} v_{t}$ is the vector of the reduced-form residuals. Following the structure of the contemporaneous coefficients matrix $B_{t}$ and that of the standard errors of the structural innovations matrix $\Sigma_{t}$, we can assume that the reduced-form residuals follow a multivariate normal distribution:

$$
\varepsilon_{t} \sim \mathcal{N}\left(0, \Omega_{t}\right)
$$

where $\Omega_{t}$ is a symmetric and positive definite time-varying variance-covariance matrix that satisfies the following equality:

$$
B_{t} \Omega_{t} B^{\prime}{ }_{t}=\Sigma_{t} \Sigma_{t}^{\prime}
$$

Allowing for such time-varying heteroskedasticity in the innovations is important for our purpose since it permits to account for changes in the size of shocks and their immediate impact.

The time paths for the parameters of interest are assumed to follow random walk processes without drift. ${ }^{4}$ If we denote $\alpha_{t}$ the column vector that contains the stacked columns of the matrix $A_{t}=\left(c_{t} A_{1, t} \cdots A_{p, t}\right), b_{t}=\left(b_{21, t} b_{31, t} b_{32, t} b_{41, t} b_{42, t} b_{43, t}\right)^{\prime}$ the column vector that gathers the elements of the matrix of the contemporaneous relationship $B_{t}$, and $h_{t}=\ln \left(\sigma_{t}\right)$ with $\sigma_{t}=\left(\sigma_{1, t} \cdots \sigma_{4, t}\right)^{\prime}$ being the column vector that contains the diagonal elements of the matrix of standard errors $\Sigma_{t}$, the parameters evolve according to:

$$
\begin{aligned}
\alpha_{t} & =\alpha_{t-1}+\omega_{t} \\
b_{t} & =b_{t-1}+\zeta_{t} \\
h_{t} & =h_{t-1}+\eta_{t}
\end{aligned}
$$

This random walk specification has two main advantages. First, it permits to model possible abrupt breaks in the evolution of parameters that might occur during the estimation period. Second, it also allows us to model gradual changes in the relationship between the variables as a result of an adaptive learning behavior of individuals. Therefore, unlike multivariate specifications used in the literature that model either structural breaks or persistence, the

\footnotetext{
${ }^{4}$ Even though the dynamics of the parameters can be easily extended to a more general autoregressive specification, we consider a random walk process in order to capture possible permanent shifts and to reduce the curse of dimensionality.
} 
TVP-VAR model encompasses these two important features of the relationship between the considered variables that might occur at different periods in our sample. In turn, innovations in the reduced-form model are assumed to be jointly normally distributed:

$$
\left(\begin{array}{c}
v_{t} \\
\omega_{t} \\
\zeta_{t} \\
\eta_{t}
\end{array}\right) \sim \mathcal{N}(0, V) \text { with } V=\left(\begin{array}{cccc}
I_{4} & 0 & 0 & 0 \\
0 & Q & 0 & 0 \\
0 & 0 & S & 0 \\
0 & 0 & 0 & W
\end{array}\right)
$$

where the matrix $V$ is block diagonal with $I_{4}, Q, S$ and $W$ corresponding to the covariance matrix of the structural innovations $v_{t}$, the innovations of lagged coefficients $\omega_{t}$, the innovations of contemporaneous coefficients $\zeta_{t}$ and the innovations of (log) standard errors $\eta_{t}$, respectively. The covariance matrix $S$ is assumed to be block diagonal, i.e. the blocks of $S$-corresponding to the contemporaneous coefficients of each individual equation in (1) are supposed to be mutually independent.

We estimate our TVP-VAR model using Bayesian methods on quarterly data from 1988Q1 to 2013Q2. To strengthen inference about the true value of the parameters, we use prior information in addition to the sample data to evaluate the posterior distributions of the parameters of interest. ${ }^{5}$ From this perspective, a critical step is to carefully choose these priors for the estimation over the actual sample period. The key priors are estimated using a time-invariant VAR process on the training sample, i.e. a small initial subsample of the dataset. To this end, we estimate a time-invariant VAR model for each studied country over the 1970Q1-1988Q1 period. ${ }^{6}$ In other words, our whole sample covers the 1970Q1-2013Q2 period, but the first 19 years of data are used as the training sample to obtain the priors for the estimation beginning in 1988Q1.

\subsection{Identification scheme}

The recent literature on oil market has evidenced that different sources of shocks can drive oil price movements by identifying three types of oil shocks: (i) changes in the world oil production that result from political and social events (war, civil unrest, OPEC decisions, ...) and that affect the supply of oil, (ii) changes in the evolution of the global economic activity that affect the demand of commodities, including oil, and (iii) changes in the expectation of agents in oil market about the state of world oil production relative to global demand that

\footnotetext{
${ }^{5}$ See Appendix for details.

${ }^{6}$ TVP-VAR models are data consuming, a property that explains why our country sample is relatively small in comparison with related studies that rely on more usual econometric methodologies.
} 
affect demand for oil inventories for speculative or precautionary motive. ${ }^{7}$ Moreover, the response of oil prices to those three shocks has been well identified by the literature, depending on the underlying source of the oil price change. Thus, the difference of sign, magnitude and persistence of the response of oil prices to those shocks offers a reliable identification scheme for structural shocks in the oil market. The signs of the restricted responses that we impose are then relatively uncontroversial and consistent with the restrictions used in most studies of the oil literature (Baumeister and Peersman, 2010; Kilian and Murphy, 2012) and of related works (Buetzer et al., 2012; Peersman and Van Robays, 2012). They can be summarized as follows. First, after a negative oil production shock, world production decreases while the oil price increases. Second, after a positive oil demand shock triggered by an unexpected rise in world economic activity, world oil production is not affected at least on the impact (zero restriction) while the oil price increases. Kilian (2009) found evidence that aggregate demand shocks increase oil production with a delay of six months. Indeed, changing oil production is costly and, thus, oil producers set their production on the basis of the expected trend growth rather than on variation in the world demand. Moreover, in line with the previous literature (Hamilton, 2003, 2008; Kilian, 2008; Baumeister and Peersman, 2013a), we consider that a rise in the oil price holds four quarters following demand shocks. Third, oil market specific shocks do not affect world oil supply on the impact (zero restriction), decrease the global economic activity and raise the oil price which also holds four quarters following oil market specific shocks. The main difference between the oil demand shocks driven by global economic activity and the speculative demand shock is that the latter have a recessionary impact on economic activity. Furthermore, the assumption that the world oil production does not react to physical and speculative demand shocks on the impact reflects the evidence that the oil supply curve is vertical in the short run (Kilian, 2009).

More technically, the structure of the variance-covariance matrix of the reduced-form residuals $\Omega_{t}$ in (5) implies a Cholesky identification scheme, restricting the contemporaneous relationship matrix to be lower triangular. This is equivalent to an exclusion restriction in the oil price literature as in Kilian (2009). Hamilton (2003) in turn uses a counterfactual experiment to identify oil supply shocks. As previously mentioned, in the present paper, we rely on sign restrictions to identify different sources of oil price fluctuations such as oil supply, global demand and speculative demand shocks (Kilian, 2009; Kilian et al., 2009; Kilian and Murphy, 2012). The sign-restriction methodology we adopt here is the Householder

\footnotetext{
${ }^{7}$ Changes in agents' expectation arise from (i) uncertainty surrounding world oil supply and global economic environment that affects demand for oil inventories without changing the level of demand and world oil production (Alquist and Kilian, 2010), (ii) revision to expected future level of world oil production, and (iii) revision to global demand of crude oil (Kilian and Murphy, 2013).
} 
Transformations of Fry and Pagan (2011) that is based on QR decomposition of randomly selected square matrices from a standard multivariate normal distribution. ${ }^{8}$ Our sign restrictions are summarized in Table 1 below.

Table 1. Sign restrictions

\begin{tabular}{lccc}
\hline & Supply shock & Global demand shock & Speculative demand shock \\
\hline Oil production & - & 0 & 0 \\
Global activity & - & + & - \\
Real price of oil & + & + (for 4 horizons) & + (for 4 horizons) \\
\hline
\end{tabular}

Note: this table reports the sign restrictions adopted to identify the different sources of oil price shocks (oil supply, global demand, speculative demand).

\section{Results}

\subsection{Sample of countries and data}

We consider a sample of five oil exporters, namely Canada, Indonesia, Norway, Saudi Arabia, and the United Kingdom, over the 1988Q1-2013Q2 period. These oil producers account for about 25 percent of the world production on the whole period and differ in terms of the role of oil in the economy. Moreover, our panel of countries covers (i) developed with high income (Canada, Norway, the United Kingdom), developing with high income (Saudi Arabia), and developing with lower middle income (Indonesia) economies; ${ }^{9}$ (ii) countries in hard peg regimes (Saudi Arabia) or in intermediate or managed floating regimes with a currency peg to the US dollar (Indonesia) or to the euro (Norway); (iii) non-inflation-targeting (Indonesia, Saudi Arabia) and inflation-targeting countries (Canada, Norway, the United Kingdom); ${ }^{10}$ (iv) OPEC (Indonesia, Saudi Arabia) and non-OPEC countries (Canada, Norway, the United Kingdom). Thus, the sample is heterogeneous enough to capture

\footnotetext{
${ }^{8}$ Moreover, as argued by Fry and Pagan (2011), the difference between Givens Matrices (GM) method and Householder Transformations (HT) method is simply a matter of computational speed. These two approaches are indeed equivalent, but HT is more efficient than GM in terms of computational speed when the size of the VAR specification grows.

${ }^{9}$ The classification between developed and developing economies reflects basic economic country conditions, while the categorization between high-income and lower middle-income developing economies refers to levels of development measured by gross national income per capita.

${ }^{10}$ We rely on Roger (2009) for the list of inflation targeting countries and their effective adoption date: Canada (1991), Norway (2001), United Kingdom (1992).
} 
changes in the relationship between the oil price and real exchange rates that may be explained by countries' specificities. ${ }^{11}$

Moreover, while the covered period differs from the mid and late 1970s in the nature of oil transactions, ${ }^{12}$ it has been marked by oil price shocks of sign and magnitude comparable to those of the 1970s (Blanchard and Gali, 2007). In particular, the period has been characterized by two episodes of oil price rises-from 1999Q1 to 2000Q2 and from 2002Q1 to 2008Q2 - which obviously raise the issue of whether they have been a significant source of real exchange rate variations in oil-producing countries. It has also coincided with several exogenous shocks to the oil market induced by political events-the Persian Gulf war of 1990-1991, the Venezuelan crisis of 2002, the Iraq war of 2003, and the Libyan uprising of 2011 (Kilian, 2014)—and by many disruptions on foreign exchange markets caused by financial crises-the crisis of the European Monetary System of 1992-1993, the Asian crisis of 1997-1998, and the financial and economic crisis of 2008-2009.

Turning to the data and as stressed above, four variables are considered at the quarterly frequency. Regarding the exchange rate series, we rely on the real effective exchange rate calculated as the weighted average of real bilateral exchange rates against each partner, and expressed in logarithmic terms. REER series are extracted from the JP Morgan effective exchange rates database. ${ }^{13}$ The three other variables are the world crude oil production (in logarithm) taken from Datastream, the real price of oil (in logarithm), and the dry-cargo index of Kilian (2009). The real oil price is defined as the average of the end-of-period nominal prices of WTI, Dubai and Brent (source: Datastream) deflated by the US consumer price index (source: Datastream). ${ }^{14}$ The dry-cargo shipping rate index developed by Kilian (2009) — available on Lutz Kilian's homepage—is a business cycle index which is designed to account for shifts in the global demand for industrial commodities. We use this index as a

11 In addition to these specificities, our choice of countries has also been guided by data availability considerations. Moreover and as previously mentioned, estimating TVP-VAR processes is highly timeconsuming, justifying the choice of a quite limited sample of economies.

${ }^{12}$ Since the OPEC cartel collapse in 1985, oil transactions are mainly current marked based (Baumeister and Peersman, 2013b).

${ }^{13}$ The effective exchange rates correspond to broad indices, which encompass not only major currencies, but also those of many emerging market economies. For more details, see Hargreaves and Strong (2003).

${ }^{14}$ As robustness checks, we have also considered two other oil price series. First, to investigate the sensitivity of our results to the price series itself, we have used the US refiners' acquisition cost of imported crude oil from the Energy Information Administration as a measure of the nominal oil price, and expressed it in real terms using US CPI as the deflator. Second, instead of considering oil price series expressed in real terms, we have implemented our analysis using the oil price in nominal terms. In both cases, we obtained results similar to those reported in this paper (complete results are available upon request to the authors). 
proxy for global economic activity, an idea that dates back to Isserlis (1938) and Tinbergen (1959). Finally, note that all those variables entering in our TVP-VAR model are stationary. ${ }^{15}$

\subsection{Time-varying real exchange rate patterns}

We start by investigating whether the response of REER to unexpected oil price shocks whatever their underlying source, has changed over time. Our interest here is then in detecting possible structural shifts in oil economies and in having a first insight regarding the potential of the time-varying oil-currency property for our selected oil-exporting countries. Figure 2 reports the dynamics of the contemporaneous relationship between the REER and the real oil price.

\section{Insert Figure 2 about here}

Except for Saudi Arabia, positive changes in the world oil price trigger a contemporaneous appreciation of the REER. As exports are highly concentrated in Saudi Arabia, the positive relationship between the oil price and REER is not necessarily explained by the prominence of the petroleum sector and dampened effects can indeed be at stake. For example, for longstanding US dollar peggers such as Saudi Arabia, studies evidence that this anchor seems to have delivered the expected benefits of this exchange rate regime, contributing to low inflation over the long term (Jadresic, 2002; Abed et al., 2003). This can then explain the remarkable stability of the real exchange rate and its observed resilience to oil price fluctuations across the time period under review. Except for the Saudi riyal, an increase in the oil price is associated with a real appreciation of the effective exchange rate. The intensity of this co-movement however differs across currencies, being more intense for Canada, Indonesia and Norway, and less pronounced for the United Kingdom.

But, the most striking feature is the significant time variation in the contemporaneous responses of real exchange rates to oil price movements. More precisely, looking at Figure 2, we can identify at least two periods in the magnitude of real exchange rates' responses to an increase in the oil price. The first spans from the beginning of our sample period to the world trade collapse (2008) where the transmission of oil prices to real exchange rates clearly varies over time, significantly increasing and reaching a peak in some countries (Canada, Indonesia, Norway) or decreasing in the United Kingdom. This period coincides with the increase in the non-OECD's oil consumption share in the world consumption, stemming mainly from a rise in China's and India's oil consumption (BP, 2014). The second period begins after the world trade collapse, where the sensibility of real exchange rates is broadly maintained at a constant level. Differences in the adjustment pattern between those two periods and within each period underline the fact that the relationship between the oil price

\footnotetext{
${ }^{15}$ Results of unit root tests are available upon request to the authors.
} 
and real exchange rates is subject to change over time, suggesting that time-varying effects are a key issue when analyzing oil currencies. Moreover, as reactions of real exchange rates to the real oil price are more fluctuating during the first period which coincides with the increase in the non-OECD's oil consumption, we should therefore expect to obtain more significant impulse responses when increases in oil prices are driven by a growing global demand. This confirms the relevance to investigate the origins of this time-varying dimension of the relationship between real exchange rates and the oil price, by distinguishing the underlying sources of oil price shocks.

\subsection{Do sources of oil price shocks matter?}

To account for the effects driven by the different sources of oil price shocks, we rely on the shocks' decomposition defined by Kilian (2009) and distinguish between oil price innovations caused by exogenous disruptions in oil supply, oil demand shocks driven by global economic activity and oil market specific demand shocks arising from speculative or precautionary motives.

We first rely on an impulse-response function (IRF) analysis to assess how the transmission of those three oil shocks to real exchange rates has changed over time. As the size of the innovations in our study is time-varying, the magnitude of impulse responses depends on the size of the shock hitting the model at each period. Therefore, the standard approach consisting in depicting the responses of the different variables following one-standarddeviation shock to one variable is not appropriate here. In order to make impulse-response functions comparable across periods, normalization is required. Thus, for each period, we consider negative oil supply and positive demand shocks of magnitude of $1 \%$. For oil market specific shocks, we assume that they generate at each period a $10 \%$ increase in the oil price. Moreover, as argued by Hamilton (2008) and Baumeister and Peersman (2013a), the greatest response of macroeconomic variables to oil price shocks occurs with a delay of around one year. Therefore, we represent in Figures 3 to 5 the REER impulse-response functions (including confidence intervals) cumulated over four quarters after the considered shock.

\section{Insert Figure 3 about here}

Figure 3 reports the impulse responses of real exchange rates to a negative oil supply shock. As shown, such a shock generates responses that oscillate moderately over time for all countries and an appreciation of the REER, except for Canada. However, for all countriesbut Indonesia before 1997 and after 2008, and Norway after 2000-the change in the REER is non-significant. As a consequence, the oil currency effect in the supply shock transmission is only found in the case of the Norwegian krone and the Indonesian rupiah. This result is 
consistent with the small historical contribution of oil supply shocks to the real price of oil. Indeed, as evidenced by Kilian (2009), oil supply disruptions had some effect on the real price of oil only in the early 1990s, but this influence was small. It therefore appears that the low sensitivity of the oil price to oil supply shocks has then mitigated, in most countries of our sample, REER changes usually associated with oil price shocks.

\section{Insert Figure 4 about here}

In contrast, as reported by Figure 4, results evidence a more statistically significant and timevarying impact of a rise in oil prices in the aftermath of an unexpected surge in global demand. This finding is in line with the previous literature that stresses the sizeable impact of such shocks on oil prices, i.e. the endogenous nature of oil prices with respect to the macroeconomic environment, considering the demand channel as a primary source of price fluctuations (Barsky and Kilian, 2002, 2004; Kilian, 2008, 2009; Hamilton, 2009).

However, the statistical significance of the oil demand shock is not observed for all countries and over the entire period: while the shock is found significant for all countries before 2003, this is no more the case for Norway and the United Kingdom after that date. Moreover, following the rise in oil prices, the REER is appreciating only in Canada and Indonesia. For this latter country, the time-changing oil price elasticity of the REER is not exclusively determined by the magnitude of demand disturbances affecting the oil market, but also by reversals in the exchange rate policy. The sizeable adjustment of the Indonesian rupiah in 1997, in the wake of the Asian crisis, has strongly amplified the response of the REER to an increase in oil prices and explains those large, oil price induced, observed shifts in the real exchange rate. ${ }^{16}$ For these two countries exhibiting an appreciating trend following the oil demand shock, the oil price elasticity of real exchange rates is, however, decreasing over time. As a consequence, if the oil currency property holds for the Canadian dollar and the Indonesian rupiah, it weakens over time, suggesting that real exchange rates of these two countries are less and less sensitive to global oil demand shocks, although their impact remains significant. In contrast, other countries of our sample undergo a depreciation of their REER following a positive oil demand shock. Here again, the sensitivity of the real exchange rates to the rise in the oil price following this shock is found to be time-varying; it weakens over time in Saudi Arabia, while becoming not significant in Norway and the United Kingdom after 2003.

Therefore, while the oil currency property holds when demand disturbances affect the oil market, it appears however to be mainly confined to some countries and to become weaker

\footnotetext{
${ }^{16}$ In the wake of the Asian crisis - that began with the floating of the Thai baht in July 1997-the Indonesian rupiah floated and, by early October, it had depreciated by 30 percent.
} 
over time, underlining the weight of domestic considerations and the time-varying nature of the oil currency effect in the oil demand shock transmission.

\section{Insert Figure 5 about here}

Finally, turning to oil market specific shocks, their impact on the REER is also time-varying, but those shocks are found to be the most significant as responses of real exchange rates are significant for all countries, except Indonesia before 1997 (Figure 5). As for the global oil demand shock, real exchange rates appreciate in the aftermath of the shock only in Canada and Indonesia, while they depreciate in the other countries of our sample. But, for all countries-except the peak in the Indonesian REER response in 1997-trends observed over time in the responses of REER after oil market specific shocks depart from those ascertained following an oil demand shock. This result supports the idea that the magnitude and the evolution of the relationship between real exchange rates and oil prices highly depend on the nature of the oil shock.

Our results evidence an amplified effect driven by oil market specific demand shocks following the Iraq war of 2003 and the global financial crisis of 2007-2008, especially for Canada, Norway and Saudi Arabia. Indeed, the response of the real exchange rate following an oil market specific shock has remained constant until 2008 in Canada and Saudi Arabia and since then has shown growing pressures to real appreciation for the Canadian dollar and decreasing pressures to real depreciation for the Saudi Arabian riyal. This latter pattern is also observed for the Norwegian REER, while beginning earlier, in the wake of the 2003 Iraq war.

Two main reasons can be given in order to explain those time-varying responses induced by oil market specific shocks. First, expectations of a future increase in the oil price driven by either political events or economic crises provide incentives to curb current oil consumption and stimulate additional oil production (Kilian, 2014), which in turn can affect the relationship between the REER and the oil price. This is then not surprising that the REER response to such shocks has been mostly effective in Canada, Saudi Arabia and Norway that are important oil-producing countries, while being inexistent in smaller oil producers like Indonesia and the United Kingdom. Second, the increased financialization of oil futures markets can matter, even if there is no clear-cut evidence of the role of speculation in driving the spot price of oil after 2003 (Fattouh et al., 2013). In particular, this process of financialization may encourage volatility spillovers both within the oil market and with financial markets which in turn impact the reaction of oil currencies to prices through a wealth effect and the demand for assets (Coudert et al., 2015). 
To sum up, as expected, higher responses of real exchange rates to oil price movements appear to be more particularly at stake when oil shocks that have been responsible for many major oil price changes over our sample period-oil demand and oil market specific shocks-prevail. In addition, interactions between the real exchange rate and the oil price vary both over time and according to the nature of the oil price shock. Consequently, analyzing the effect of oil price shocks without distinguishing their underlying sources over time could be misleading. In particular, responses of real exchange rates to oil price movements evidence the presence of offsetting factors that vary over time and that arise from compensating effects between the two oil demand shocks. Moreover, depending on both the type of shocks and the time period considered, we also observe, for a given country and across countries, significant evolutions and differences, as summarized in Table 2.

Table 2. Statistical significance and sign of impulse responses to oil shocks

\begin{tabular}{|c|c|c|c|}
\hline & Supply shock & Global demand shock & $\begin{array}{l}\text { Specific demand } \\
\text { shock }\end{array}$ \\
\hline Canada & & $1988-2013(+)$ & $1988-2013(+)$ \\
\hline Indonesia & $\begin{array}{c}1988-1997 ; 2008-2011 \\
(+)\end{array}$ & 1988-2012 (+) & $1997-2013(+)$ \\
\hline Norway & 2000-2013 (+) & 1988-2003 (-) & 1988-2013 (-) \\
\hline Saudi Arabia & & $1988-2013(-)$ & 1988-2013 (-) \\
\hline United & & 1988-2003 (-) & $1988-2013(-)$ \\
\hline Kingdom & & & \\
\hline
\end{tabular}

This heterogeneity between countries found over time and for each type of oil shock points to the importance of domestic considerations that also affect the dynamics of REER and the real price of oil.

\subsection{Identifying drivers of real exchange rates over time}

To understand the underlying mechanisms that have been driving real exchange rates' fluctuations in the considered oil-producing countries, we perform both historical (Figure 6) and variance (Figure 7) decompositions. These two complementary tools are used in order to analyze the evolution of the size of structural innovations and to measure the contribution of each innovation to the evolution of real exchange rates. While the Forecast Error Variance Decomposition (FEVD) consists in decomposing the variance of the forecast error of the real exchange rate $h$ periods ahead, the historical decomposition consists in explaining the observed values of real exchange rates in terms of the structural shocks. As for the impulse 
responses, we allow the FEVD to vary over time, thus enabling for alternating dynamics in the composition of shocks that drive the variances. ${ }^{17}$

\section{Insert Figures 6 and 7 about here}

For all countries, Figures 6 and 7 show that oil shocks explain the main part of real exchange rate changes. Interestingly, this overall picture must be qualified as our countries exhibit diverging patterns over time. As expected, for economies where oil production significantly declined over time-Indonesia (since 1999) and the United Kingdom (since 1990)_our results emphasize a lower influence of oil shocks on real exchange rates particularly after 2000. These two countries shifted from a position of net oil exporters to net oil importers (since 2003 and 2004 respectively). In countries where oil represents a significant share of exports, Figures 6 and 7 suggest that time profiles differ more significantly. Canada is clearly the most "oil currency" country as not only oil shocks explain the main part of real exchange rate changes, but also their importance increases over time. At the opposite, Norway seems the least "oil currency" in the sense that the influence of oil shocks on REER accounts for the weakest part of real exchange rate changes over the studied period. However, the impact of oil shocks follows an increasing trend since 2000. Saudi Arabia is in an intermediate position insofar as oil shocks represent a higher (lower) share of real exchange rate changes than Norway (Canada).

Several explanations could be put forward to account for this heterogeneity between countries. Natural arguments can be sought in the importance of various dampening factors, clearly identified by the literature on oil-producing countries. This particularly holds for countries like Norway and Saudi Arabia which manage their oil revenues through an active policy to isolate their economy from sharp and erratic price movements that characterize the oil market. This policy mainly takes the form of an accumulation of exchange-rate reserves (Figure 8) and/or an increase in foreign assets through Sovereign Wealth Funds (SWFs). Specifically, while in Saudi Arabia, there is no separate wealth fund from the Saudi Arabian Monetary Agency to manage oil revenues, Norway owns such fund. According to the Norwegian Ministry of Finance, the market value of the Government Pension Fund Global has risen from 55 billion USD in 2001 to more than 879 billion in 2014. SWFs are especially important to the extent that they prevent a full conversion of oil revenues in domestic currency insofar as part of these revenues can be invested abroad. In other words, they act as a "quasi-sterilization" instrument for domestic authorities (Habib and Kalamova, 2007;

\footnotetext{
17 The decompositions are calculated for a 30 quarters horizon, thus representing the medium-term impact of shocks.
} 
Buetzer et al., 2012). ${ }^{18}$ In those countries, the main oil price shock transmission mechanism should then be channeled through the fiscal policy rather than through the real exchange rate (Steigum and Thøgersen, 1995; El Anshasy and Bradley, 2011).

Similarly, we can expect that monetary authorities of inflation-targeting countries also raise interest rates in an effort to curb inflationary pressure, driven by a rise in world oil prices (Manera and Cologni, 2008). However, findings concerning Canada suggest that the importance of monetary regimes must not be overestimated. Specifically, while this country has adopted an inflation-targeting regime, it does not rely on SWFs contrary to Saudi Arabia and Norway. ${ }^{19}$ Regarding oil-producing countries that peg their currencies to the US dollar, if a rise in oil prices is absorbed by USD depreciation, the exchange rate policy may dampen the effect of oil prices on real exchanges rates (Reboredo, 2012). As a consequence, the experiences of Norway (inflation-targeting country) and Saudi Arabia (conventional peg regime) suggest that the transmission of oil prices to real exchange rates can be limited by an appropriate combination between monetary and fiscal policies.

Besides policy responses to oil prices changes, structural factors can explain differences between Canada, Norway, and Saudi Arabia. As exhibited in Table 3, it is worth mentioning that Canada is characterized by specific properties compared to other oil-exporting countries (Kilian et al., 2009): (i) it is a diversified country with manufactured goods exports representing about $54 \%$ of total exports, but is among the top ten oil exporters despite the quite limited oil share (19\%) in its total exports; and (ii) it owns the third largest proved crude oil reserve after Saudi Arabia and Venezuela. ${ }^{20}$ These specific characteristics confer to Canada a prominent role in the oil market, but do not entirely shelter the economy and especially the Canadian dollar from oil price volatility.

\footnotetext{
${ }^{18}$ Various other factors can also dampen the contribution of oil prices to REER movements as the degree of financial integration and financial development (Kilian et al., 2009), and valuation effects (Kilian et al., 2009; Buetzer et al., 2012; Wang et al., 2013).

${ }^{19}$ Up to 1983,30 percent of the petroleum incomes were channeled into the fund (Alberta Heritage Savings Trust Fund created in 1976). This value was reduced to 15 percent during the 1984-87 period, before the payments into the fund went down to zero. Since then there have been no additional payments into the fund.

${ }^{20}$ According to the U.S. Energy Information Administration and the Oil \& Gas Journal, the proved reserve of Canada amounts to 173 billion barrels while that of Venezuela and Saudi Arabia amounts to 297 and 278 billion of barrels, respectively.
} 
Table 3. Share of fuels and manufactured goods in GDP and trade (\%)

\begin{tabular}{|c|c|c|c|c|c|}
\hline Exports & Canada & Indonesia & Norway & $\begin{array}{l}\text { Saudi } \\
\text { Arabia }\end{array}$ & $\begin{array}{l}\text { United } \\
\text { Kingdom }\end{array}$ \\
\hline \multirow{3}{*}{$\begin{array}{c}\text { Fuels / Total exports } \\
\text { Manufactured goods / Total } \\
\text { exports } \\
\text { Fuels / GDP } \\
\text { Manufactured goods / GDP }\end{array}$} & 19.2 & 28.5 & 64.0 & 85.1 & 9.7 \\
\hline & 54.4 & 42.2 & 18.8 & 12.8 & 70.5 \\
\hline & $\begin{array}{c}5.7 \\
16.1\end{array}$ & $\begin{array}{c}7.5 \\
11.1 \%\end{array}$ & $\begin{array}{c}20.6 \\
6.1\end{array}$ & $\begin{array}{c}41.1 \\
6.2 \\
\end{array}$ & $\begin{array}{c}1.7 \\
12.3 \\
\end{array}$ \\
\hline Imports & Canada & Indonesia & Norway & $\begin{array}{l}\text { Saudi } \\
\text { Arabia }\end{array}$ & $\begin{array}{l}\text { United } \\
\text { Kingdom }\end{array}$ \\
\hline \multirow{2}{*}{$\begin{array}{c}\text { Fuels / Total imports } \\
\text { Manufactured goods / Total } \\
\text { imports }\end{array}$} & 8.4 & 19.5 & 4.9 & 0.2 & 8.4 \\
\hline & 78.0 & 63.6 & 77.8 & 70.8 & 69.0 \\
\hline $\begin{array}{c}\text { Fuels / GDP } \\
\text { Manufactured goods / GDP }\end{array}$ & $\begin{array}{c}2.3 \\
21.4\end{array}$ & $\begin{array}{c}4.4 \\
14.3\end{array}$ & $\begin{array}{c}0.9 \\
14.8\end{array}$ & $\begin{array}{l}0.04 \\
14.0\end{array}$ & $\begin{array}{c}2.0 \\
16.1\end{array}$ \\
\hline
\end{tabular}

Sources: UNCTAD database and authors' calculations. Averages of annual data over the 1995-2013 period.

The previous trends about the influence of oil as a driver of real exchange rate fluctuations hide interesting differences concerning the contribution of the underlying sources of oil price shocks to REER innovations. The oil supply shock is the weakest driver of real exchange rates for all countries but Norway. In other words, differences in the degree of oil exports' concentration do not matter. Such finding is in line with the literature stressing the relative low influence of oil supply shocks on macroeconomic variables in oil-importing countries. As shown in Figures 6 and 7, while real exchange rates tend to be mainly explained by oil demand shocks in the 1990s in Canada, Indonesia, Saudi Arabia and the United Kingdom, the influence of these shocks decreases in the 2000s. Indeed, over this latter sub-period, we identify a dramatic increase in the impact of oil specific shocks on the real exchange rate dynamics. Clearly, oil demand specific shocks are found to be the most significant ones in assessing real exchange rate changes across countries and over time. Historical and forecast error variance decompositions provide similar results, emphasizing the robustness of our findings.

\section{Conclusion}

This paper has investigated the time-varying property of the relationship between the real price of oil and real effective exchange rates for a sample of five oil exporters. Specifically, we account for time-changing effects of oil shocks and the evolving oil price transmission to real exchange rates through the estimation of a time-varying parameter VAR model. Acknowledging that different kinds of shocks may have distinct effects, we distinguish between three types of oil shocks: exogenous disruption in oil supply, oil demand shocks 
driven by global economic activity, and oil-specific demand shocks coming from speculative and precautionary motives.

Considering the 1988Q1-2013Q2 period, we find evidence that the relationship between the real price of oil and real effective exchange rates has evolved through time and that the source of shocks strongly matters in explaining this time-varying property. Specifically, while oil supply shocks play a small role in explaining the relationship between oil prices and real exchange rates, when they lead to significant responses, the real exchange rate-oil price nexus appears to be remarkably constant. In contrast, oil demand shocks are shown to have a sizeable effect, over the 1988-2003 period. Indeed, those shocks cause time-varying relationships between real exchange rates and oil prices which, however, tend to offset each other. However, the appreciation of real exchanges rates following a demand-driven rise in oil prices is only confined to some countries, suggesting that in addition to endogenous structural changes in the oil market, both economic policies and structural characteristics matter as driving forces behind the adjustment of real exchanges rates to oil price shocks.

Our results thus provide additional insights on the gap between the theoretical literature and the empirical literature on oil currencies. Indeed, the result that the oil currency property in oil countries can be driven by different sources of oil price shocks changing over time gives a new picture of the oil currency phenomenon, compared to that delivered by the existing oil literature. The oil currency property cannot be considered as the oil producers' model but rather refers to different hybrid models in the sense that conditional to each country, oil currency may be driven by one or several sources of oil price shocks that furthermore can vary over time. 


\section{References}

Abed, G., Erbas, N. and Guerami, B., 2003. The GCC monetary union: Some considerations for the exchange rate regime, IMF Working Paper WP/03/66, International Monetary Fund, Washington, D.C.

Ahmad, A.H. and Moran Hernandez, R., 2013. Asymmetric adjustment between oil prices and exchange rates: Empirical evidence from major oil producers and consumers, Journal of International Financial Markets, Institutions and Money 27, 306-317.

Akram, Q.F., 2004. Oil prices and exchange rates: Norwegian evidence, Econometrics Journal $7(2), 476-504$.

Alquist, R. and Kilian, L., 2010. What do we learn from the price of crude oil futures?, Journal of Applied Econometrics, 25(4), 539-573.

Atems, B., Kapper, D. and Lam, E., 2015. Do exchange rates respond asymmetrically to shocks in the crude oil market?, Energy Economics 49, 227-238.

BP, 2014. BP Statistical Review of World Energy. Data can be found on the BP website: http://www.bp.com/en/global/corporate/about-bp/energy-economics/statistical-review-ofworld-energy.html.

Barsky, R.B. and Kilian, L., 2002. Do We Really Know that Oil Caused the Great Stagflation? A Monetary Alternative, In B. Bernanke and K. Rogoff (eds.), NBER Macroeconomics Annual 2001, May 2002, 137-183.

Barsky, R.B. and Kilian, L., 2004. Oil and the Macroeconomy since the 1970s, Journal of Economic Perspectives 18(4), 115-134.

Baumeister, C. and Peersman, G., 2010. Sources of the Volatility Puzzle in the Crude Oil Market, Working Papers of Faculty of Economics and Business Administration, Ghent University, Belgium 10/634, Ghent University, Faculty of Economics and Business Administration.

Baumeister, C. and Peersman, G., 2013a. Time-Varying Effects of Oil Supply Shocks on the US Economy, American Economic Journal: Macroeconomics 5(4), 1-28.

Baumeister, C. and Peersman, G., 2013b. The Role of Time-Varying Price Elasticities in Accounting for Volatility Changes in the Crude Oil Market, Journal of Applied Econometrics 28(7), 1087-1109.

Beckmann, J. and Czudaj, R., 2013. Is there a homogeneous causality pattern between oil prices and currencies of oil importers and exporters?, Energy Economics 40, 665-678. 
Blanchard, O. and Gali, J., 2007. The Macroeconomic Effects of Oil Shocks: Why are the 2000s So Different from the 1970s?, NBER Working Papers 13368, National Bureau of Economic Research, Cambridge, MA.

Buetzer, S., Habib, M.M. and Stracca, L., 2012. Global exchange rate configurations: do oil shocks matter?, European Central Bank Working Paper No. 1442.

Carter, C.K. and Kohn, R., 1994. On Gibbs sampling for state space models, Biometrika 81, 541-553.

Cashin, P., Cespedes, L. F. and Sahay, R., 2004. Commodity currencies and the real exchange rate, Journal of Development Economics 75(1), 239-268.

Chen, S.-S. and Chen, H.-C., 2007. Oil prices and real exchange rates, Energy Economics 29, 390-404.

Chen, Y. and Rogoff, K., 2003. Commodity Currencies, Journal of International Economics $60(1), 133-160$.

Chen, Y., Rogoff, K. and Rossi, B., 2010. Can Exchange Rates Forecast Commodity Prices?, Quarterly Journal of Economics 125(3), 1145-1194.

Cogley, T. and Sargent, T.J., 2005. Drift and Volatilities: Monetary Policies and Outcomes in the Post WWII US, Review of Economic Studies 8(2), 262-302.

Corden, W.M., 1984. Booming Sector and Dutch Disease Economics: Survey and Consolidation, Oxford Economic Papers 35, 359-380.

Coudert, V., Couharde, C. and Mignon, V., 2011. Does Euro or Dollar Pegging Impact the Real Exchange Rate? The case of oil and commodity currencies, The World Economy 31 (9), 1557-1592.

Coudert, V., Couharde, C. and Mignon, V., 2015. On the impact of oil price volatility on the real exchange rate - terms of trade nexus: Revisiting commodity currencies, Journal of International Money and Finance 58, 110-127.

El Anshasy, A. A. and Bradley, M. D., 2011. Oil prices and the fiscal policy response in oilexporting countries, Journal of Policy Modeling 34, 605-620.

Fattouh, B., Kilian, L. and Mahadeva, L., 2013. The Role of Speculation in Oil Markets: What Have We Learned So Far?, The Energy Journal 34(3), 7-33.

Fry, R. and Pagan, A., 2011. Sign Restrictions in Structural Vector Autoregressions: A Critical Review, Journal of Economic Literature 49(4), 938-60.

Golub, S., 1983. Oil prices and exchange rates, The Economic Journal 93 (371), 576-593. 
Habib, M.M. and Kalamova, M.M., 2007. Are there oil currencies ? The real exchange rate of oil exporting countries, ECB Working Paper Series, $n^{\circ} 839$, December.

Hahn, E. and Mestre, R., 2011. The role of oil prices in the Euro area economy since 1970s, ECB Working Paper Series $n^{\circ} 1356$, June.

Hamilton, J.D., 2003. What is an Oil Shock?, Journal of Econometrics 113, 363-398.

Hamilton, J.D., 2008. Oil and the Macroeconomy, in Durlauf, S.N. and Blume, L. (eds), The New Palgrave Dictionary of Economics, Palgrave Macmillan.

Hamilton, J.D., 2009. Causes and Consequences of the Oil Shock of 2007-08, Brookings Papers on Economic Activity 40, 215-283.

Hargreaves, D. and Strong, C., 2003. JPMorgan effective exchange rates: revised and modernized, Economic Research note (New York: J.P. Morgan Chase Bank, May).

Isserlis, L., 1938. Tramp Shipping Cargoes and Freights, Journal of the Royal Statistical Society 101(1), 53-134.

Jadresic, E., 2002. On a Common Currency for the GCC Countries, IMF Policy Discussion Paper (PDP/02/12), International Monetary Fund: Washington, D.C.

Kilian, L., 2008. A Comparison of the Effects of Exogenous Oil Supply Shocks on Output and Inflation in the G7 Countries, Journal of the European Economic Association 6(1), 78-121.

Kilian, L., 2009. Not All Oil Price Shocks Are Alike: Disentangling Demand and Supply Shocks in the Crude Oil Market, American Economic Review 99(3), 1053-1069.

Kilian, L., 2014. Oil Price Shocks: Causes and Consequences, Annual Review of Resource Economics 6(1), 133-154.

Kilian, L. and Murphy, D.P., 2012. Why Agnostic Sign Restrictions Are Not Enough: Understanding the Dynamics of Oil Market VAR Models, Journal of the European Economic Association 10(5), 1166-1188.

Kilian, L. and Murphy, D.P., 2013. The role of inventories and speculative trading in the global market for crude oil, Journal of Applied Econometrics, 29(3), 454-478.

Kilian, L., Rebucci, A. and Spatafora, N., 2009. Oil shocks and external balances, Journal of International Economics 77(2), 181-194.

Kim, S., Shepard, N. and Chib, S., 1998. Stochastic volatility: likelihood inference and comparison with ARCH models, Review of Economic Studies 65, 361-393.

Korhonen, I. and Juurikkala, T., 2009. Equilibrium exchange rates in oil-exporting countries, Journal of Economics and Finance 33(1), 71-79. 
Krugman, P., 1983. Oil and the dollar, in Bhandari, J. and Putnam, B. (eds), Economic interdependence and flexible exchange rates, MIT Press.

Le, T.H. and Chang, Y., 2013. Oil price shocks and trade imbalances, Energy Economics 36, 78-96.

Manera, M. and Cologni, A. 2008. Oil Prices, Inflation and Interest Rates in a Structural Cointegrated VAR Model for the G-7 Countries, Energy Economics 30(3), 856-888.

Mohammadi, H. and Jahan-Parvar, M.R., 2012. Oil prices and exchange rates in oilexporting countries: evidence from TAR and M-TAR models, Journal of Economics and Finance 36(3), 766-779.

Peersman, G. and Van Robays, I., 2009. Oil and the Euro area economy, Economic Policy 24(60), 603-651.

Peersman, G. and Van Robays, I., 2012. Cross-country differences in the effects of oil shocks, Energy Economics 34, 1532-1547.

Primiceri, G. E., 2005. Time Varying Structural Vector Autoregressions and Monetary Policy, Review of Economic Studies 72(3), 821-852.

Raymond, J.E. and Rich, R.W., 1997. Oil and the macroeconomy: A Markov state-switching approach, Journal of Money, Credit and Banking 29(2), 193-213.

Reboredo, J.C., 2012. Modelling oil price and exchange rate co-movements, Journal of Policy Modeling 34, 419-440.

Roger, S., 2009. Inflation targeting at 20: Achievements and challenges, IMF Working Paper 09/236, International Monetary Fund.

Steigum, E. and Thøgersen, $\varnothing ., 1995$. Petroleum wealth, debt policy, and intergenerational welfare: The case of Norway, Journal of Policy Modeling 17(4), 427-442.

Tinbergen, J., 1959. Tonnage and Freight, in Jan Tinbergen Selected Papers, Amsterdam: North Holland, 93-111.

Wang, Y., Wu, C. and Yang, L., 2013. Oil price shocks and stock market activities: Evidence from oil-importing and oil-exporting countries, Journal of Comparative Economics 41(4), 1220-1239. 
Figure 1. Evolution of real effective exchange rates and real oil price $(1988=100)$

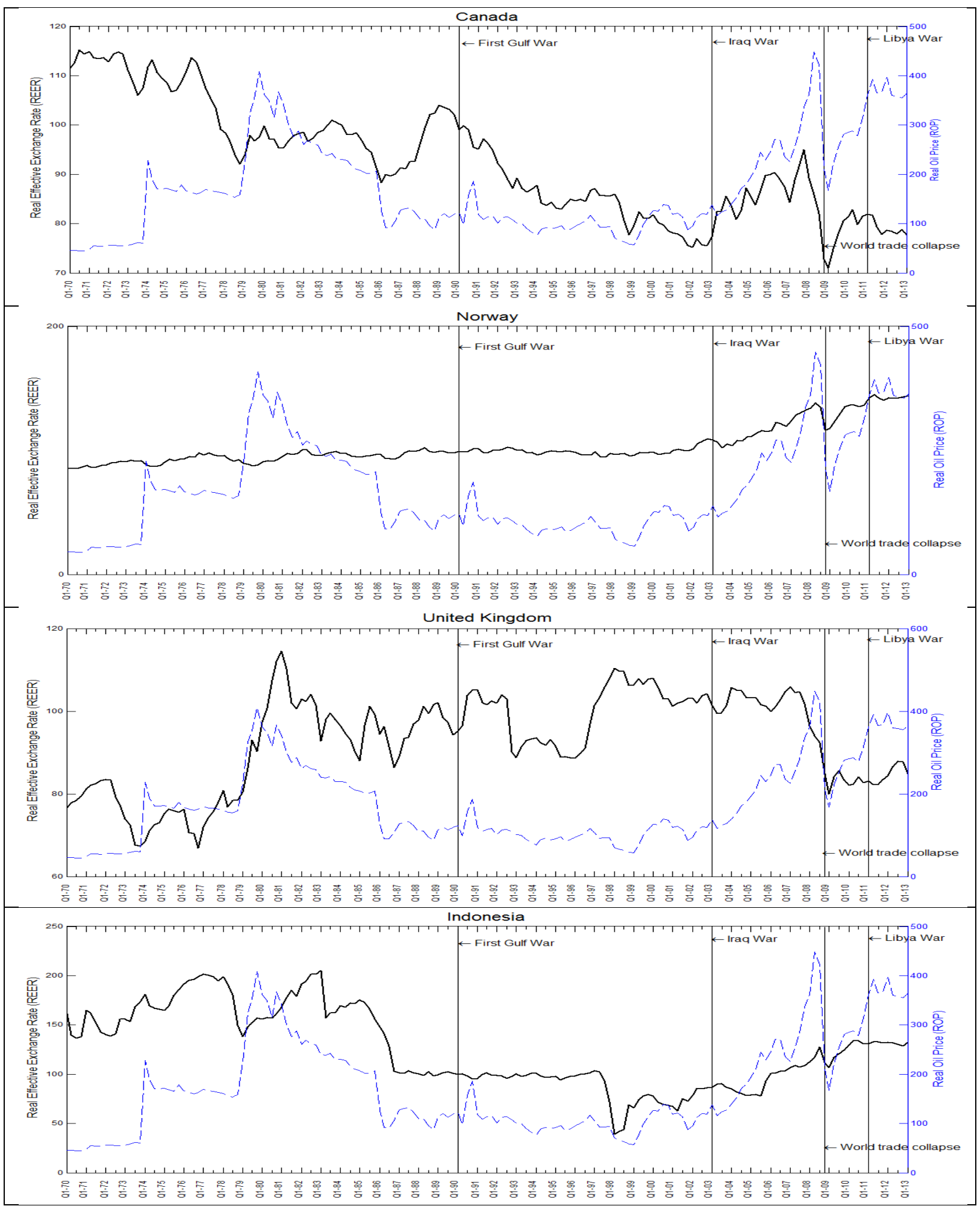




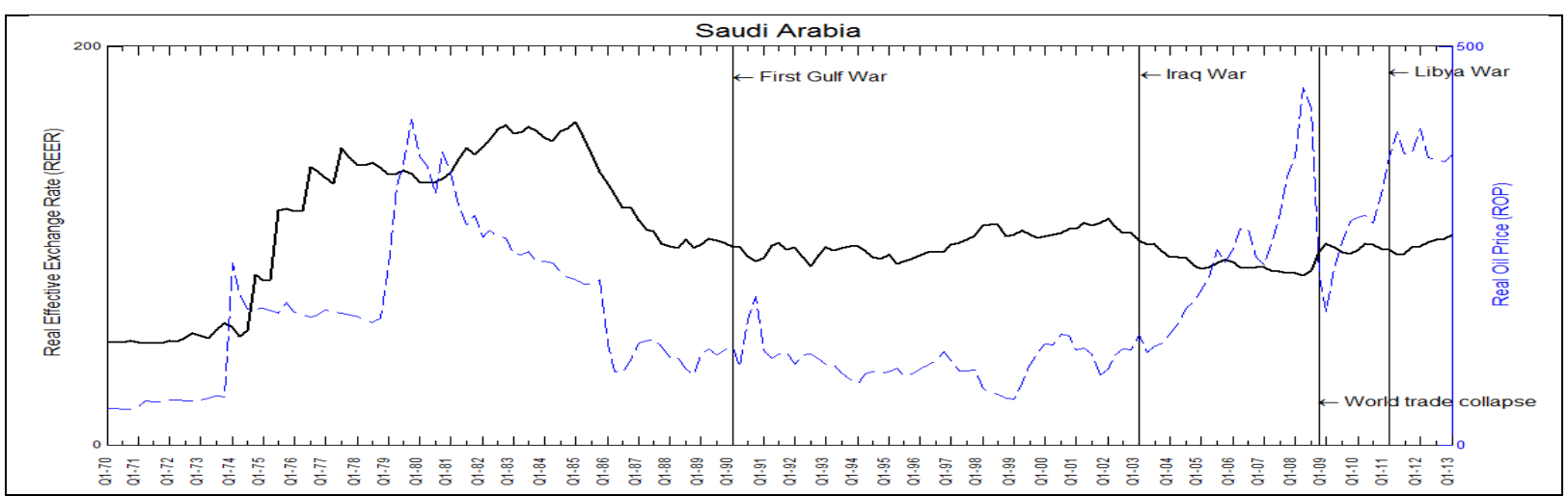

Note: the black line represents the evolution of the REER (left scale) and the blue dashed line, the evolution of the real oil price (right scale). See Section 3.1 for data sources. 
Figure 2. Contemporaneous link between REER and real oil price

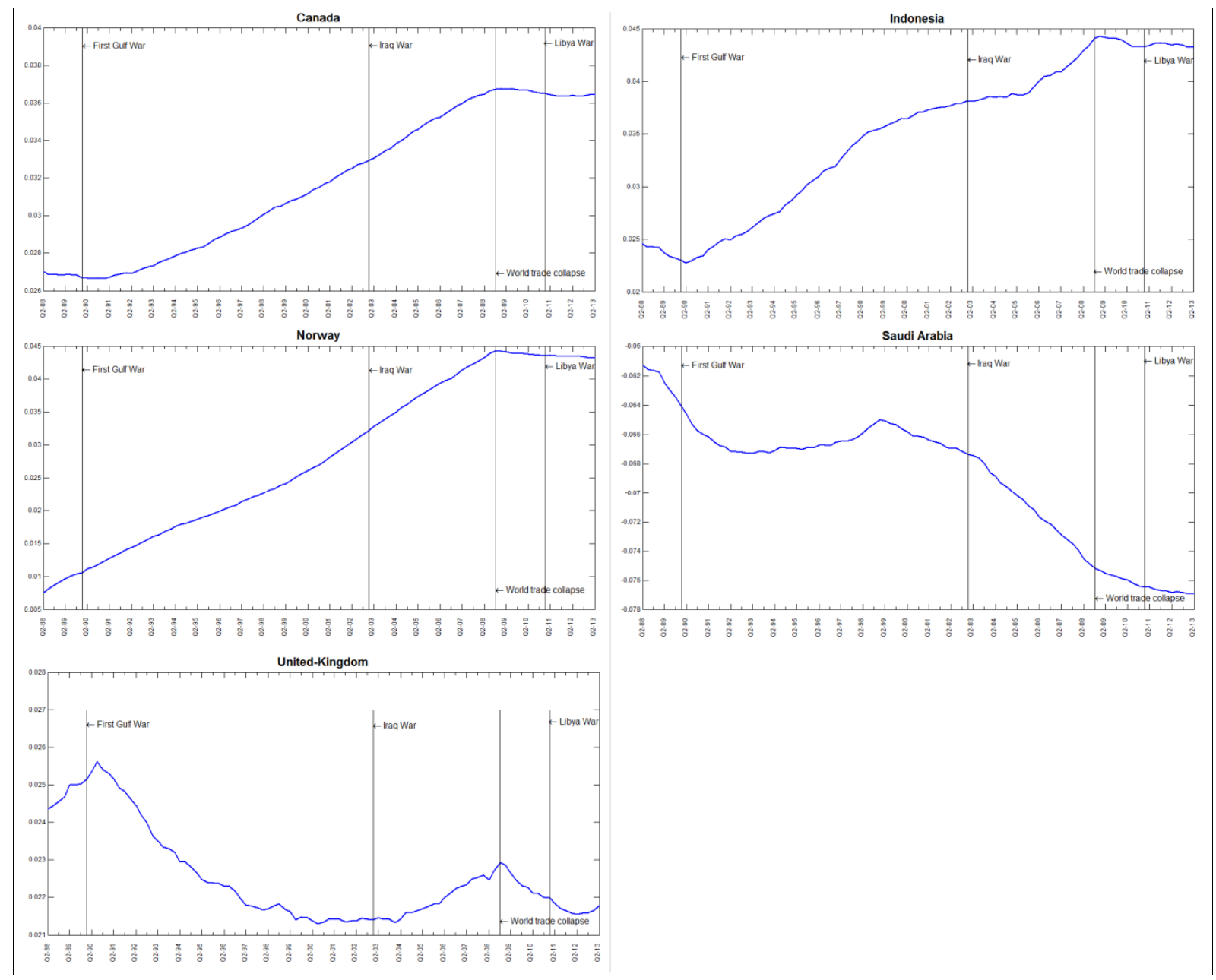

Note: this figure displays the dynamics of the contemporaneous relationship between the real effective exchange rate and the real oil price for each country. 
Figure 3. REER impulse response following an oil production shortfall (horizon: 4 quarters)

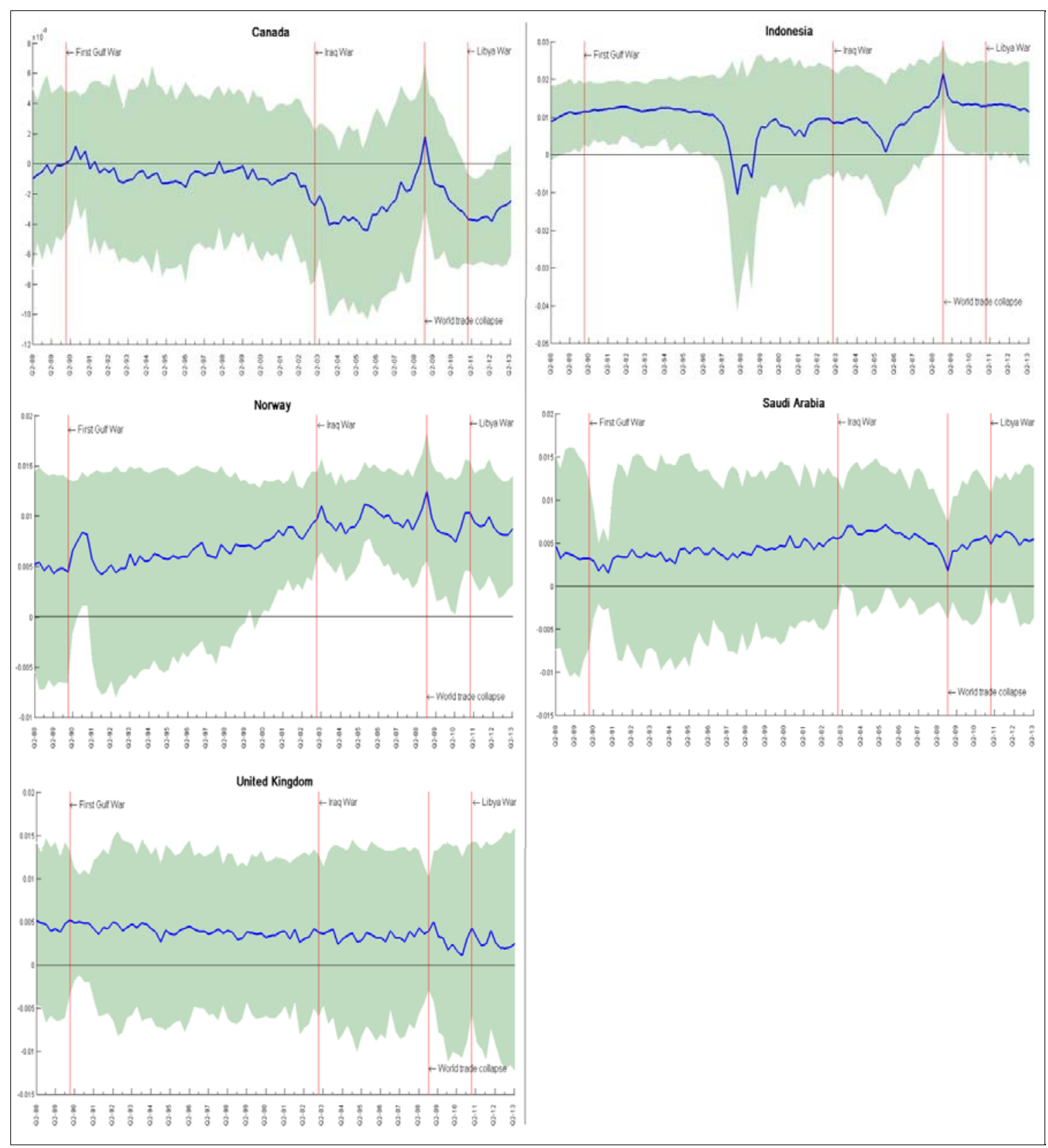

Note: this figure reports the impulse-response functions (in blue) of real effective exchange rates to a negative oil supply shock, with the corresponding confidence interval (in green). 
Figure 4. REER impulse response following a world oil demand shock (horizon: 4 quarters)

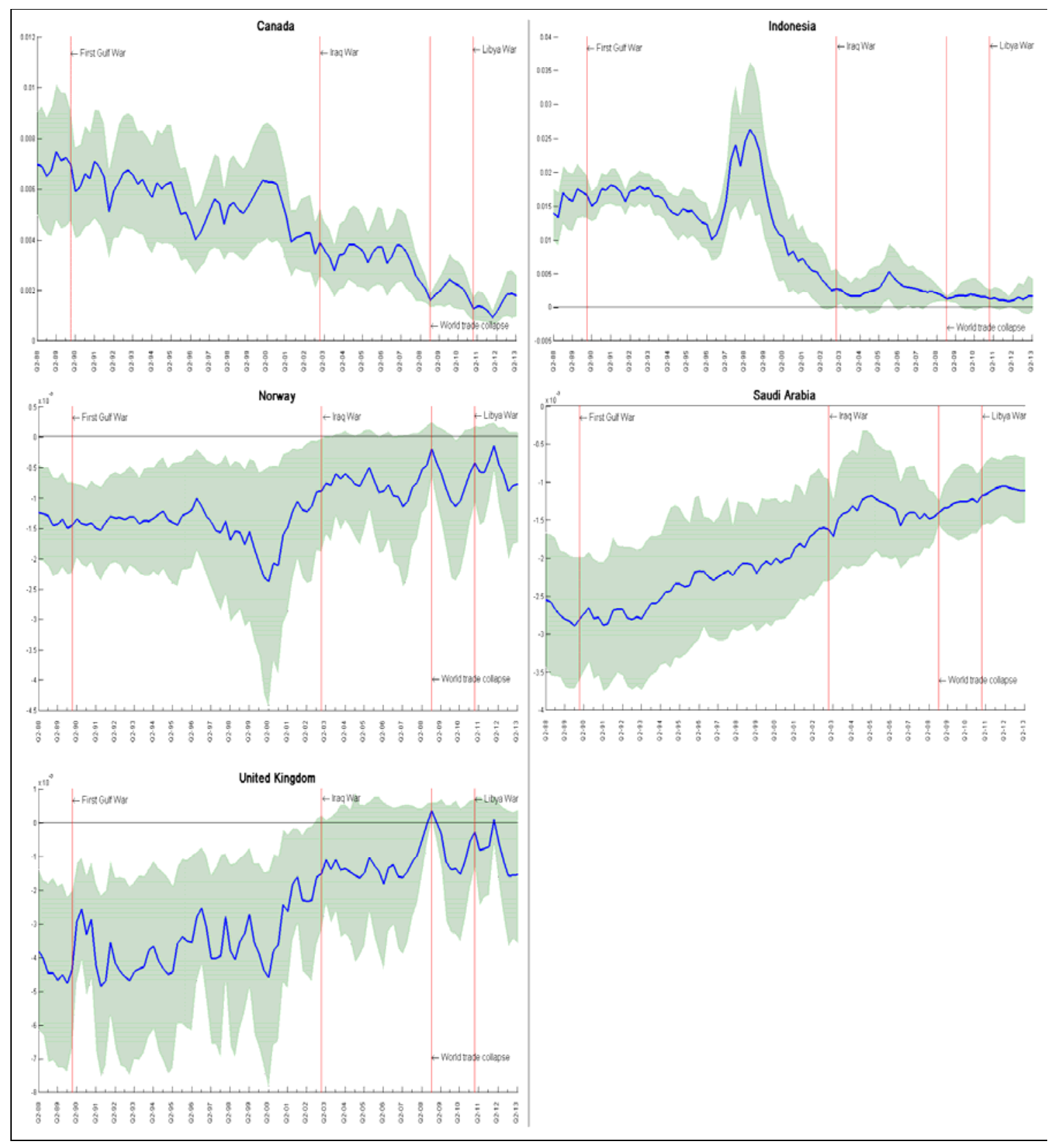

Note: this figure reports the impulse-response functions (in blue) of real effective exchange rates to a world oil demand shock, with the corresponding confidence interval (in green). 
Figure 5. REER impulse response following an oil-specific demand shock (horizon: 4 quarters)

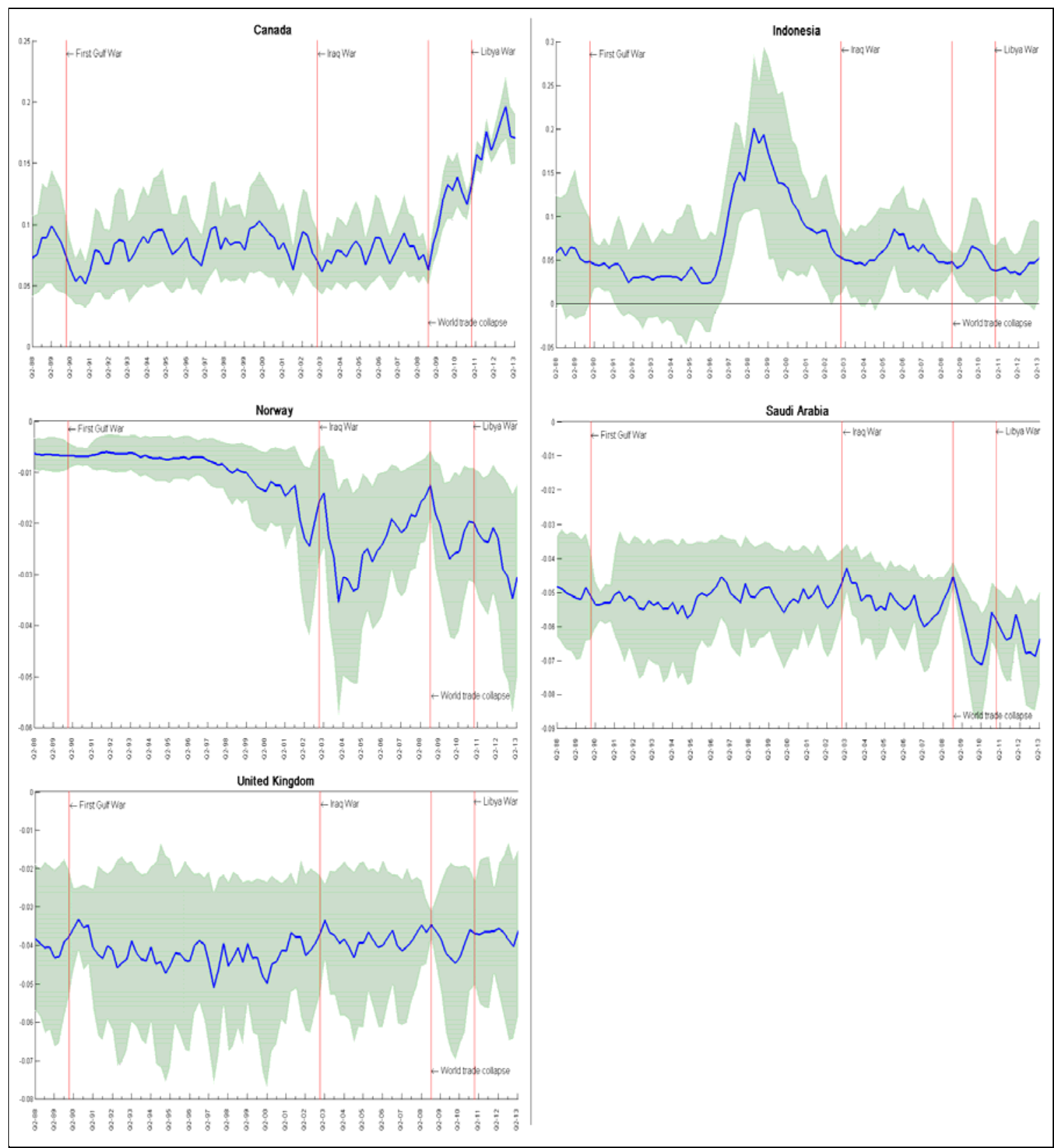

Note: this figure reports the impulse-response functions (in blue) of real effective exchange rates to an oil market specific shock, with the corresponding confidence interval (in green). 
Figure 6. Historical decomposition of the REER

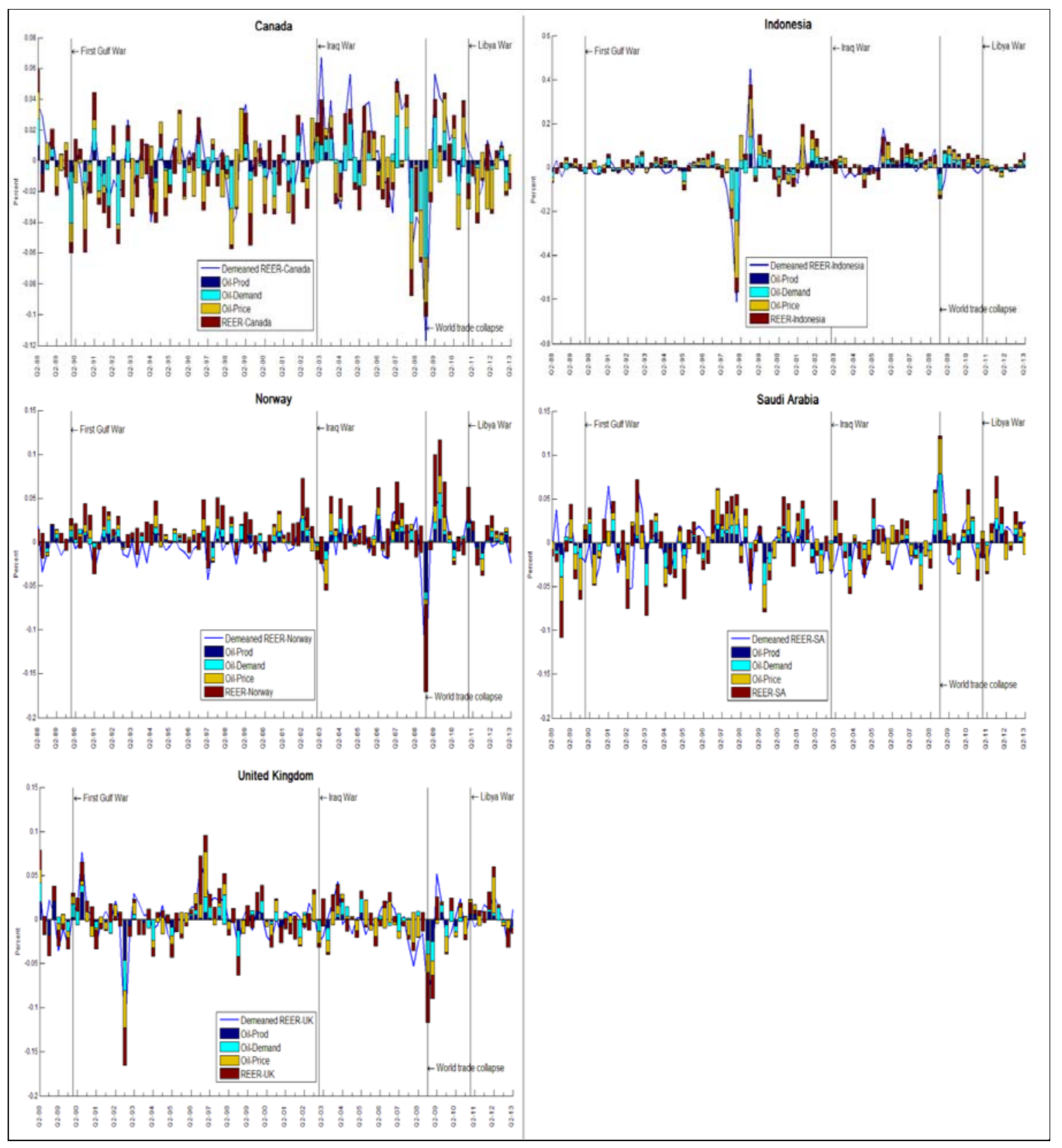

Note: this figure reports the historical decomposition of real effective exchange rates (REER) for each country according to the nature of the oil shock (Oil-Prod: oil supply shock, OilDemand: oil global demand shock, Oil-Price: oil-specific demand shock). 
Figure 7. Forecast Error Variance Decomposition of the REER

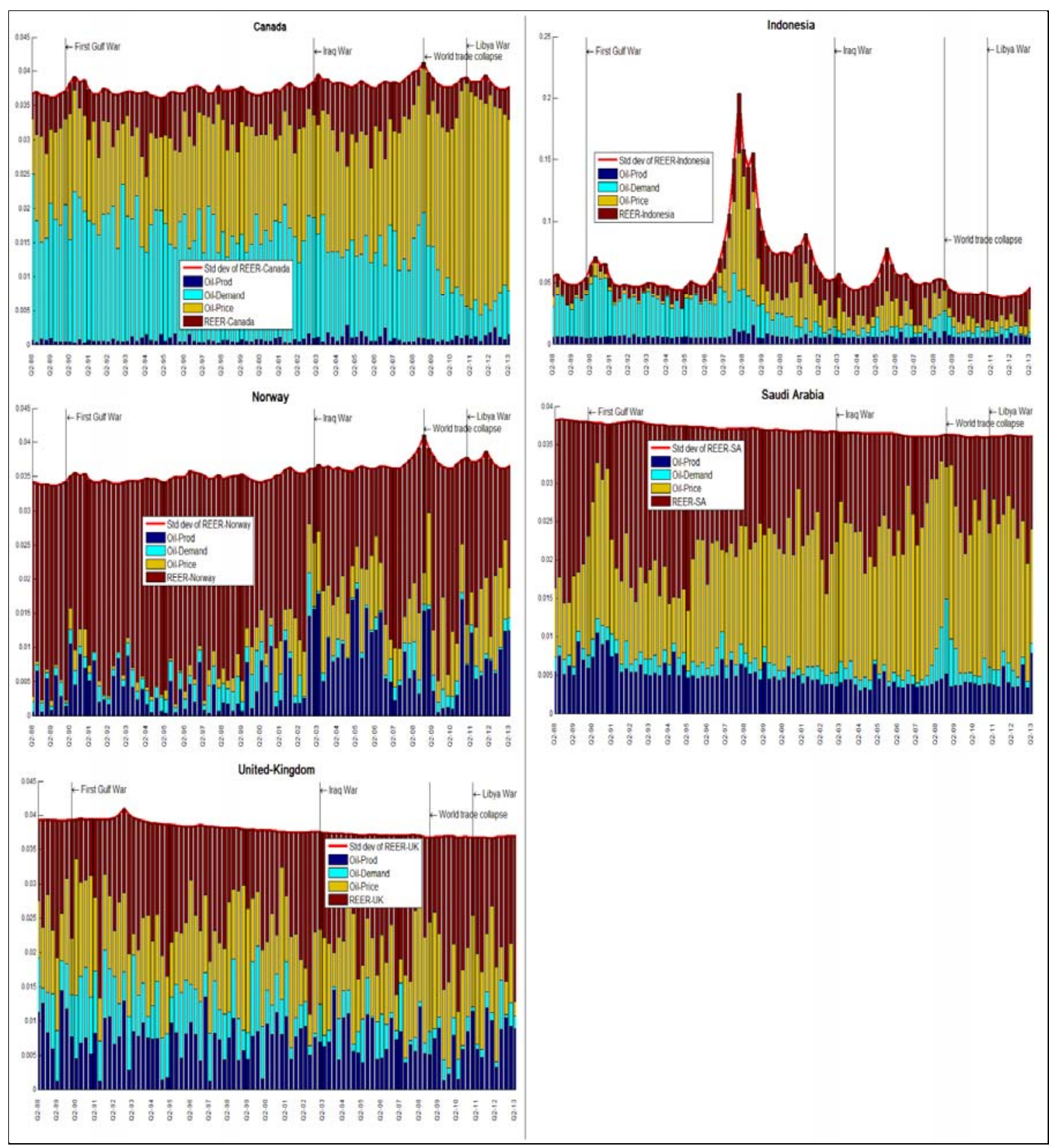

Note: this figure reports the forecast variance error decomposition of real effective exchange rates (REER) for each country according to the nature of the oil shock (Oil-Prod: oil supply shock, Oil-Demand: oil global demand shock, Oil-Price: oil-specific demand shock). 
Figure 8. Foreign exchange reserves 1988-2013, in U.S. dollar billion

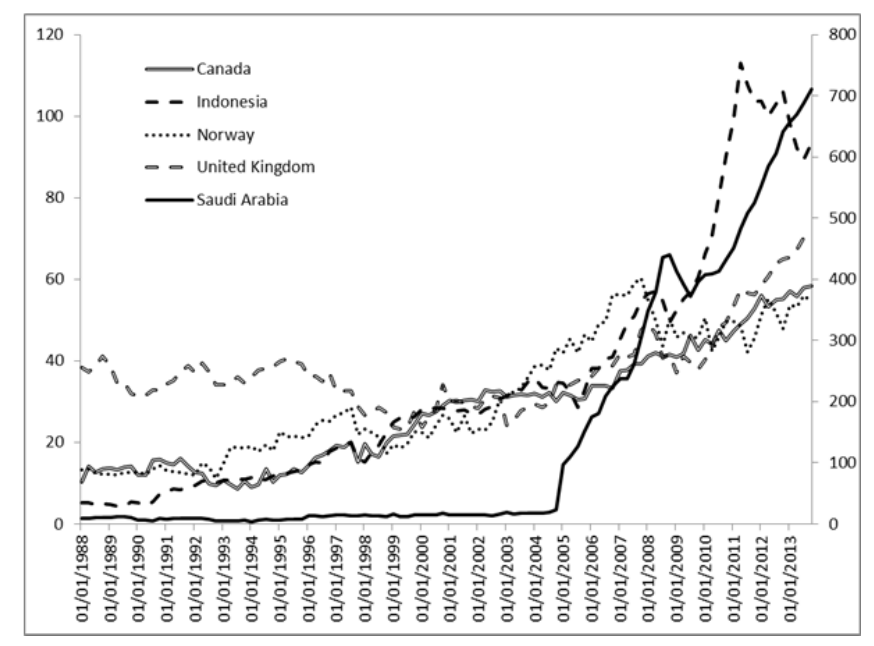

Source: International Monetary Fund, International Financial Statistics 


\section{Appendix}

\section{A1. Bayesian inference}

As in Cogley and Sargent (2005), the parameters of interest $A_{t}, B_{t}$ and $\Sigma_{t}$ are expressed in a state-space representation. Based on (i) the reduced-form equation (3), (ii) the law of motion of parameters (4), and (iii) the normality assumption of innovations $v_{t}$ and $\omega_{t}$, the lag coefficients $A_{t}$ have a linear Gaussian state-space representation. In turn, the lower triangular, diagonality and bloc diagonality assumptions of $B_{t}, \Sigma_{t}$ and $S$ ensure a linear Gaussian state-space representation of contemporaneous coefficients. Therefore, the joint posterior density for $A_{t}$ and $B_{t}$ is a product of independent normal distributions. However, the standard-error coefficients in $\Sigma_{t}$ can be transformed into a linear state-space representation which is no longer Gaussian. Instead, they follow a $\ln \left(\chi^{2}(1)\right)$ distribution, which can be approximated by a mixture of 7 normal distributions as in Kim et al. (1998).

The entire sequence of the parameters of interest $A_{t}, B_{t}$ and $\Sigma_{t}$ is generated via forward and backward recursion of Kalman filter using Gibbs sampler; estimates of parameters being obtained using Carter and Kohn (1994)'s simulation smoother.

\section{A2. Prior distribution}

Our specifications of prior distributions follow Primiceri (2005). The initial values for the timevarying parameters and variance-covariance matrices are assumed to be mutually independent. An initial training sample of 80 observations is used to generate OLS point estimates of the parameters of interest. Priors of the initial values of the reduced-form VAR parameters $A_{o}$, the contemporaneous coefficients $B_{o}$, and the logarithm of volatilities $\ln \Sigma_{o}$ are assumed to follow a normal distribution with mean equals to the corresponding OLS estimates of the parameters and variance equals to four times the corresponding OLS variances for $A_{o}$ and $B_{o}$, and equals to the identity matrix for $\ln \Sigma_{o}$ :

$$
\begin{gathered}
\alpha_{0} \sim \mathcal{N}\left(\hat{\alpha}_{\text {ols }}, 4 . V\left(\hat{\alpha}_{\text {ols }}\right)\right) \\
b_{0} \sim \mathcal{N}\left(\hat{b}_{\text {ols }}, 4 . V\left(\hat{b}_{\text {ols }}\right)\right) \\
h_{0} \sim \mathcal{N}\left(\hat{h}_{\text {ols }}, I_{n}\right)
\end{gathered}
$$

with $n$ denoting the number of endogenous variables in the system $(n=4)$.

In turn, the priors of different blocks of the variance-covariance matrix $V$ are assumed to be independent and to follow an inverted Wishart $(\mathcal{J W})$ distribution: 


$$
\begin{gathered}
Q \sim \mathcal{J W}\left(k_{Q}^{2} \cdot 80 \cdot V\left(\hat{b}_{o l s}\right), 80\right) \\
S_{[i]} \sim \mathcal{J W}\left(k_{S}^{2} \cdot(i+1) \cdot V\left(\hat{b}_{o l s}\right),(i+1)\right) \\
W \sim \mathcal{J W}\left(k_{W}^{2} \cdot(n+1) \cdot I_{n},(n+1)\right)
\end{gathered}
$$

where $k_{Q}^{2}=0.01, k_{S}^{2}=0.1, k_{W}^{2}=0.01, n=4$, and $S_{[i]}$ corresponds to the $i^{\text {th }}$ block of the matrix $S$. It should be noticed that these priors assumptions together with the random walk hypothesis in (6) imply normal priors on the entire sequences of $A_{t}, B_{t}$ and $\Sigma_{t}$ conditional on $Q, S$ and $W$. Using this setting, the priors are not flat but sufficiently diffuse and uninformative to let the data determine the best estimates of parameters.

\section{A3. Posterior distribution}

Given that the state-space model of parameters of interest are linear and Gaussian, the posterior distributions of the state variables $\alpha_{t}\left|Y_{t}, B_{t}, \Sigma_{t}, S, b_{t}\right| Y_{t}, \alpha_{t}, \Sigma_{t}, S$ and $h_{t} \mid Y_{t}, \alpha_{t}, B_{t}, W$ are generated using forward and backward recursion of Kalman filter. Variance-covariance matrices $Q, S$ and $W$ are generated from their respective independent posterior distributions which are assumed to follow an inverted Wishart distribution:

$$
\begin{gathered}
Q \mid Y_{t}, A_{t}, B_{t}, \Sigma_{t} \sim \mathcal{J W}\left(\left(\sum_{t=p+1}^{T} \omega_{t} \omega_{t}^{\prime}+\underline{Q}\right),(T-p+\underline{q})\right) \\
S_{[i]} \mid Y_{t}, A_{t}, B_{t}, \Sigma_{t} \sim \mathcal{J W} \mathcal{W}\left(\left(\sum_{t=p+1}^{T} \zeta_{[i] t} \zeta_{[i] t}^{\prime}+\underline{S_{[i]}}\right),\left(T-p+\underline{S_{[i]}}\right)\right) \\
W \mid Y_{t}, A_{t}, B_{t}, \Sigma_{t} \sim \mathcal{J W}\left(\left(\sum_{t=p+1}^{T} \eta_{t} \eta_{t}^{\prime}+\underline{W}\right),(T-p+\underline{w})\right)
\end{gathered}
$$

where $\underline{Q}, \underline{S_{[i]}}$ and $\underline{W}$ are positive definite scale matrices from the inverted Wishart prior distributions of $Q$, block matrix $S_{[i]}$ of $S$ and $W ; \underline{q}, \underline{s_{[i]}}$, $\underline{w}$ being their respective degrees of freedom. 


\section{A4. Markov Chain Monte Carlo (MCMC) algorithm}

The implementation procedure of the Markov Chain Monte Carlo (MCMC) algorithm can be summarized as follows:

1. Specify the initial sequence of $A_{t}, B_{t}, \Sigma_{t}, D_{t}$ and $V$,

2. Generate the states $\alpha_{t}$ conditional on $Y_{t}, B_{t}, \Sigma_{t}$ and $Q$ using Kalman filter for $t=1, \ldots, T$,

3. Generate off-diagonal elements $b_{t}$ of the contemporaneous matrix $B_{t}$ conditional on $Y_{t}, \alpha_{t}$, $\Sigma_{t}$ and $S$, using Kalman filter for $t=1, \ldots, T$,

4. Generate volatilities $\sigma_{t}$ conditional on $Y_{t}, \alpha_{t}, b_{t}, D_{t}$ and $W$ using Kalman filter for $t=$ $1, \ldots, T$,

5. Generate a new selection matrix $D_{t}$ by sampling from $P\left(d_{i t}=k \mid Y_{i t}^{* *}, h_{i t}\right)$ conditional on $Y_{t}$, $\alpha_{t}, b_{t}, \sigma_{t}$ for $t=1, \ldots, T$,

6. Generate variance-covariance matrix $V$ by sampling from independent inverted Wishart distribution,

7. Check for stationarity of the VAR, and if and only if it is the case, store parameters of interest,

8. Go to step 2.

It is worth noting that step 7 is implemented in order to ensure that realizations of the VAR are stationary; only stationary draws being accepted and stored. 